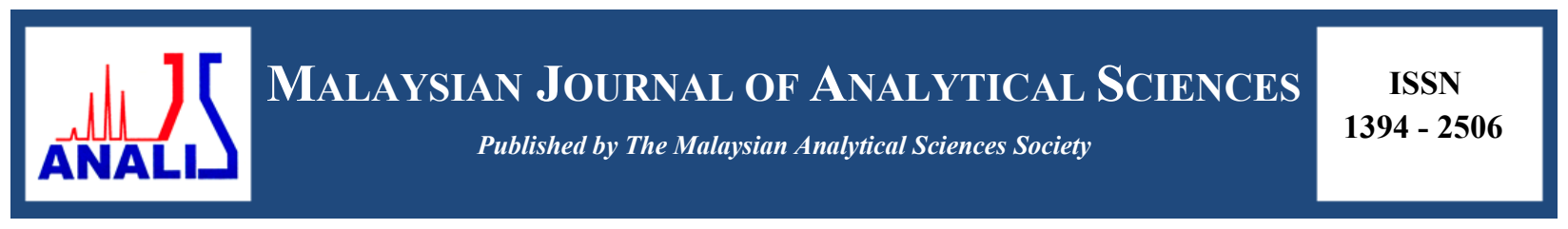

\title{
PREPARATION AND CHARACTERIZATION OF DIFFERENT LOADING OF ZINC OXIDE ON ACTIVATED CARBON NANOFIBERS
}

\author{
(Penyediaan dan Pencirian Gentian-Nano Karbon Teraktif Pada Kepekatan Zink Oksida Yang \\ Berbeza)
}

Faten Ermala Che Othman, Norhaniza Yusof*, Amirul Afiat Raffi, Hasrinah Hasbullah, Farhana Aziz, Wan Norharyati Wan Salleh, Ahmad Fauzi Ismail

Advanced Membrane Technology Research Centre,

Faculty of Chemical \& Energy Engineering,

Universiti Teknologi Malaysia, 81310 Skudai, Johor Bahru, Malaysia

*Corresponding author: norhaniza@petroleum.utm.my

Received: 26 August 2016; Accepted: 8 January 2017

\begin{abstract}
The study deals on the modified PAN-based activated carbon nanofibers (ACNFs) embedded with different amount of zinc oxides $(\mathrm{ZnO})(0,5,10$, and $15 \%$ relative to PAN wt.) to be used as adsorbents for natural gas adsorption. The nanofibers (NFs) were successfully fabricated via electrospinning process at optimize parameters. The resultant NFs underwent three steps of pyrolysis process which are stabilization, carbonization and activation at optimum parameters. The morphological structure and diameter of pure and modified ACNFs were characterized using SEM while the existences of chemical bonds were analyzed by FTIR analysis. XRD analysis was done to identify the crystallinity of the ACNFs. BET method was used to identify the specific surface area (SSA) and nitrogen adsorption isotherm of the samples. The results showed that the SSA of ACNF5 $\left(163.04 \mathrm{~m}^{2} / \mathrm{g}\right)$ is significantly higher compared to the pristine and other modified ACNFs, nevertheless the obtained results is much lower compared to average theoretical value. SEM micrograph depicted that all ACNF samples possessed average diameter of $300-$ $500 \mathrm{~nm}$ with smooth and aligned structure. The presence of white spots as ZnO alongside the NFs has been confirmed with FTIR and XRD analysis. From these findings, it is believed that ACNFs/ZnO will become a new adsorbent with great potential for gas adsorption and storage in the near future applications.
\end{abstract}

Keywords: activated carbon nanofibers, zinc oxide, polyacrylonitrile, specific surface area

\begin{abstract}
Abstrak
Kajian ini membincangkan tentang gentian-nano karbon teraktif (ACNFs) terubah suai berasaskan polimer PAN yang digabungkan dengan kandungan zink oksida $(\mathrm{ZnO})$ yang berbeza $(0,5,10$, dan $15 \%$ berdasarkan berat PAN) untuk digunakan sebagai penjerap dalam penjerapan gas asli. Gentian-nano (NFs) telah berjaya direka melalui proses putaran elektro menggunakan parameter-paramter optimum daripada kajian terdahulu. Kemudian, NFs yang terbentuk akan melalui tiga peringkat proses pirolisis iaitu penstabilan, karbonisasi, dan pengaktifan menggunakan parameter optimum daripada kajian terdahulu. Struktur morfologi dan diameter ACNFs tulen dan yang telah diubahsuai dengan ZnO telah dicirikan menggunakan SEM manakala kewujudan ikatan kimia telah dianalisis menggunakan FTIR. Selain itu, untuk mengenalpasti penghabluran ACNFs yang terhasil, analisis yang dikenali sebagai XRD telah dijalankan. Kaedah BET pula dijalankan untuk mengenal pasti luas permukaan tertentu (SSA) dan isoterma penjerapan nitrogen. Hasil kajian menunjukkan bahawa SSA sampel ACNF5 $\left(163,04 \mathrm{~m}^{2} / \mathrm{g}\right)$ adalah lebih tinggi berbanding dengan ACNFs tulen atau ACNFs yang telah diubahsuai yang lain..Walau bagaimanapun, keputusan yang diperoleh menunjukkan SSA yang jauh lebih rendah berbanding dengan nilai teori purata. Melalui SEM mikrograf, semua sampel ACNFs yang dihasilkan melalui kajian ini memiliki diameter purata dari 300 hingga 500 $\mathrm{nm}$ dengan struktur licin dan sejajar. Kehadiran bintik putih sebagai ZnO telah disahkan melalui analisis FTIR dan XRD.
\end{abstract}


Penemuan ini membuktikan bahawa ACNFs/ZnO akan menjadi penjerap baru yang mempunyai potensi besar dalam aplikasi penjerapan dan penyimpanan gas pada masa hadapan.

Kata kunci: gentian karbon teraktif, zink oksida, poliakrilonitril, luas permukaan spesifik

\begin{abstract}
Introduction
Activated carbon (AC) has been widely utilized as adsorbent in various applications in recent years included in water or gas adsorption due to their porous structure, high specific area, and cost-friendly [1]. Currently, AC can be developed by using various types of precursors such as pitch, lignin, polymers, and also synthetic precursor, however polyacrylonitrile (PAN)-based adsorbents have become an attractive alternative as PAN precursor could produce high carbon yield up to $56 \%$ as compared to the other precursors [2]. However, a new enhanced material known as activated carbon nanofibers (ACNFs) with highly microporous structure with finer structure and greater specific surface area [3] have been developed in order to overcome the disadvantages of AC that possessed low SSA and limited the gas adsorption capabilities. Ascribed by its low resistance to bulk flow, high adsorption-desorption kinetics, heat stability, and high strength; PAN-based ACNFs have received major attention from researcher all over the globe and were studied for their potential as excellent gas adsorbents [4].
\end{abstract}

Nanofibers (NFs) can be fabricated by various techniques included template synthesis, phase separation, electrospinning, and self-assembly [5]. Out of those available techniques, electrospinning seems to produce NFs with smaller diameter with uniform distribution structures. Moreover, electrospinning offers more advantages than other techniques such as versatility, efficiency, and feasibility in large quantities production. Recently, in order to improvised the NFs structures, the electrospun NFs were subjected to activation process to create new macropores and micropores structures, with smaller fiber diameter and greater SSA. Furthermore, incorporation of additives such as metal oxide into the NFs was proven can enhance the structure of the NFs. Metal oxide nanoparticles such as magnesium oxide $(\mathrm{MgO})$, manganese dioxide $\left(\mathrm{MnO}_{2}\right)$, zinc oxide $(\mathrm{ZnO})$, and nickel oxide $(\mathrm{NiO})$ have been profound to be as excellent candidate that could enhance the physicochemical properties of PAN-based ACNFs due to their catalytic effects [6]. These nanoparticles themselves are high in SSA and the addition of right amount of these nanoparticles into the NFs solution are believed could improve their structure as well as adsorption capabilities.

In this study, the ACNFs embedded with $\mathrm{ZnO}$ were produced through suitable electrospinning and activation method under optimum parameters obtained from previous studies [7]. The objective of this present study is to prepare the ACNFs incorporated with $\mathrm{ZnO}$ and to study their microstructural properties and surface area for suitable gas adsorbent materials.

\title{
Nanofibers fabrication
}

\section{Materials and Methods}

The polymer polyacrynitrile (PAN) and solvent N, N-dimethylformamide (DMF) were purchased from SigmaAldrich while zinc oxide $(\mathrm{ZnO})$ powder was purchased from Alfa Aesar. Homogenous DMF solutions of PAN containing $0,5,10$, and $15 \%$ (relative to PAN wt.) of $\mathrm{ZnO}$ were stirred gently for 24 hours at room temperature. The nanofibers (NFs) were prepared by using a lab-scale electrospinning machine NFOM1000-1503 supplied from Nfiber at optimum voltage of $12.4 \mathrm{kV}$, the distance between the needle tip to collector of $20 \mathrm{~cm}$, and flow rate of 1 $\mathrm{ml} /$ hour. The resultant NFs with $0,5,10$, and $15 \%$ of $\mathrm{ZnO}$ were denoted as NF0, NF5, NF10, and NF15, respectively.

\section{Activation of nanofibers}

The resultant NFs were underwent three stages of pyrolysis process. Start with stabilization with pure air until the temperature of $275^{\circ} \mathrm{C}$, followed by carbonization under inert air condition until $600{ }^{\circ} \mathrm{C}$, and finally activation with activating gas such as carbon dioxide until $800{ }^{\circ} \mathrm{C}$, in order to improve the porous structure of the NFs and directly increasing the specific surface area with 30 minutes of resting time for each stage. After activation, the NFs were known as activated carbon nanofibers (ACNFs). In this study, ACNFs with $0,5,10$, and $15 \%$ of $\mathrm{ZnO}$ were denoted as ACNF0, ACNF5, ACNF10, and ACNF15, individually. 


\section{Characterization}

In order to better understanding of the PAN-based $\mathrm{ACNF} / \mathrm{ZnO}$ produced, there are several characterization analyses have been conducted. The morphology and diameter of the NFs have been characterized using field emission scanning electron microscopy (FESEM) while the elemental analysis and chemical studies of the NFs were analyzed by using X-ray diffraction (XRD) analysis and Frontier Transform Infrared (FTIR) analysis, respectively. Moreover, Brunauer-Emmett-Teller (BET) analysis was used in order to study specific surface area and pore size distribution of all the resultant NFs. The surface area and microspore analysis of NFs and ACNFs were investigated using nitrogen gas $\left(\mathrm{N}_{2}\right)$ adsorption isotherm at $77 \mathrm{~K}$ (ASAP2020, Micromeritics, USA).

\section{Morphological studies of nanofibers}

\section{Results and Discussion}

Figure 1 shows the SEM images of PAN-based ACNF/ZnO with different loading of $\mathrm{ZnO}$ prior activation. It can be seen that the all NFs possessed smooth, straight, and aligned structure with several white spots attached alongside the fibers (Figure 1b,c, d) that represent the existence of $\mathrm{ZnO}$. The fibers diameter was varied in all concentrations. From the figure, it obviously can be seen that the pristine NFs possessed the largest fiber diameter as compared to $\mathrm{NFs}$ embedded with $\mathrm{ZnO}$. It was found that addition of $\mathrm{ZnO}$ has reduced the diameter of the NFs up to $45 \%$, with average diameter of NF0 is $576.8 \pm 55.91 \mathrm{~nm}$ and was reduced to $325 \pm 43.1 \mathrm{~nm}$ in all modified NFs (NFs embedded with $\mathrm{ZnO}$ ).

After activation, the NFs were transformed into activated carbon nanofibers (ACNFs) and the SEM photographs of all pristine and modified ACNFs are shown in Figure 2. It can be seen that the ACNFs possessed rougher, irregular, and undulated structure compared to NFs prior activation. The average diameter of the all NFs also decreased up to $40 \%$ from $450 \mathrm{~nm}$ to $270 \mathrm{~nm}$ due to the removal of PAN and other molecules during the heat treatment resulting in weight loss and NFs' diameter reduction [8,9]. As shown in Figure 2(b), ACNF5 possessed the finest fiber structure with well-dispersed and a few agglomeration of $\mathrm{ZnO}$ alongside/inside the ACNFs as compared to the others.
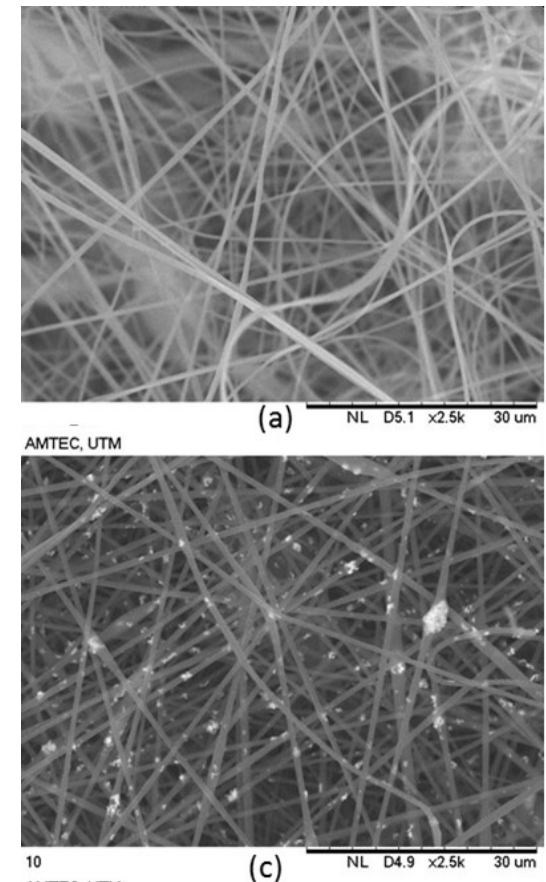

AMTEC, UTM (c)

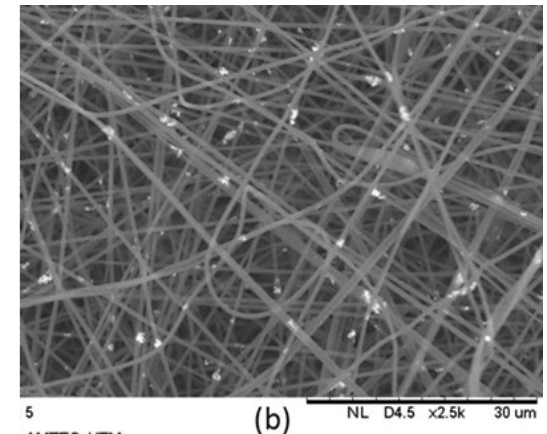

AMTEC, UTM

(b)

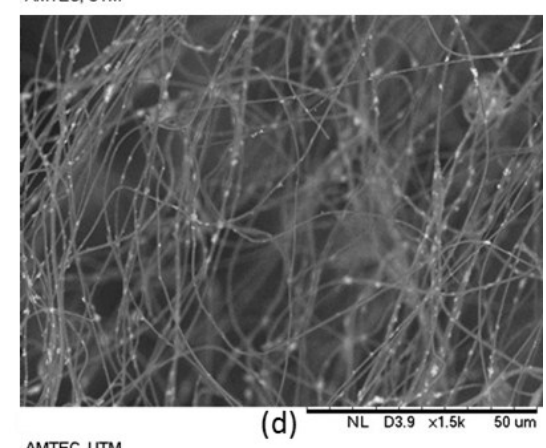

AMTEC, UTM

Figure 1. SEM micrograph of nanofibers with different loading of zinc oxide prior activation (a) NF0, (b) NF5, (c) NF10 at 2500x magnification and (d) NF15 at 1500x magnification 


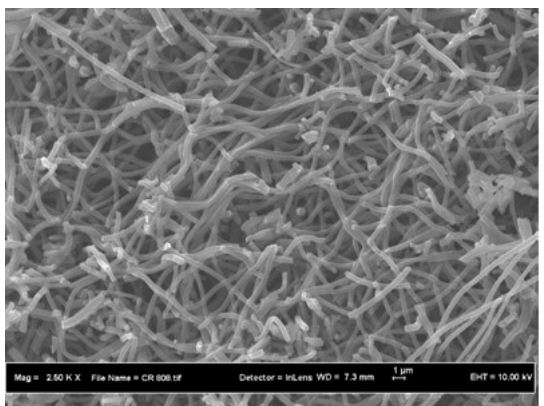

(a)

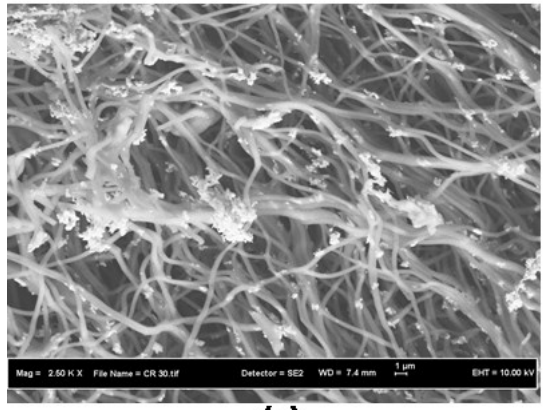

(c)

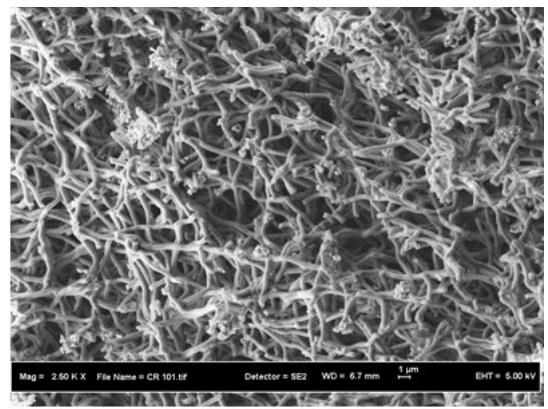

(b)

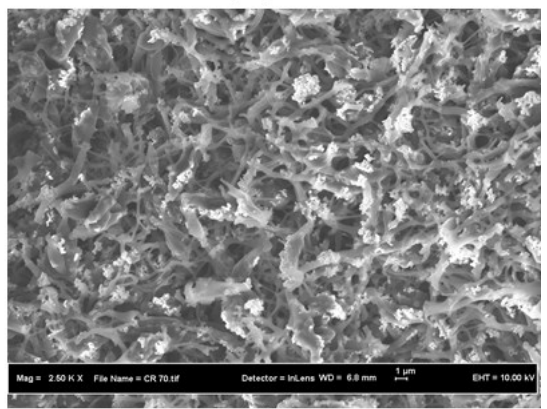

(d)

Figure 2. SEM micrograph of nanofibers with different loading of zinc oxide after activation (a) ACNF0, (b) ACNF5, (c) ACNF10, and (d) ACNF15 at 2500x magnification

Although this result counterback the result of previous research conducted by Dadvar et al. [6], as they said the increasing the amount of metal oxide loaded, the smaller the diameter of the NFs; this study has concluded that NFs were only affected by the amount of metal oxide, which is up to its maximum loading depends on the type of the metal oxide used in order to produce NFs with better structure. This phenomenon is believed could start as early as during the dope preparation and fiber preparation stages as the amount and types of the metal oxide used can affect the viscoelasticity of the solution and varies the ejection time of jet to arrive at the collector and these behaviors are believed to give impact to the diameter of the NFs [10].

\section{Chemical bond studies}

Figure 3 shows the FTIR spectra for NFs embedded with 0 and $5 \%$ of $\mathrm{ZnO}$ prior and after activation. As can be seen, there are various peaks appeared in the NFs prior activation (Figure 3a) and some of the peaks were removed after activation due to heat treatment (Figure 3b), and it is believed only carbon and hydrogen peaks were left. Theoretically, numerous new transition structures were formed during pyrolysis. As can be seen in Figure 3(a), there are five major peaks can be detected in both NF0 and NF5 that represent different vibrations existed in the NFs prior activation. However, there is one high peak was detected at wavenumber $445.7 \mathrm{~cm}^{-1}$ in NF5 that represents $\mathrm{Zn}-\mathrm{O}$ vibrations [11, 12]. Nevertheless, the appearance of unknown peak around wavenumber $400-700$ $\mathrm{cm}^{-1}$ in Figure 3 is believed due to the existence of other vibrations that overlapped at the same wavenumber range such as $\mathrm{C}-\mathrm{C}, \mathrm{C}-\mathrm{N}$, and $\mathrm{C}-\mathrm{O}$. After activation, there are only three major peaks were detected at 1285.5, 1433.1, and $1581.7 \mathrm{~cm}^{-1}$ represent $\mathrm{C}=\mathrm{O}, \mathrm{C}-\mathrm{H}$, and $\mathrm{C}=\mathrm{C}$ vibrations, respectively [13]. 

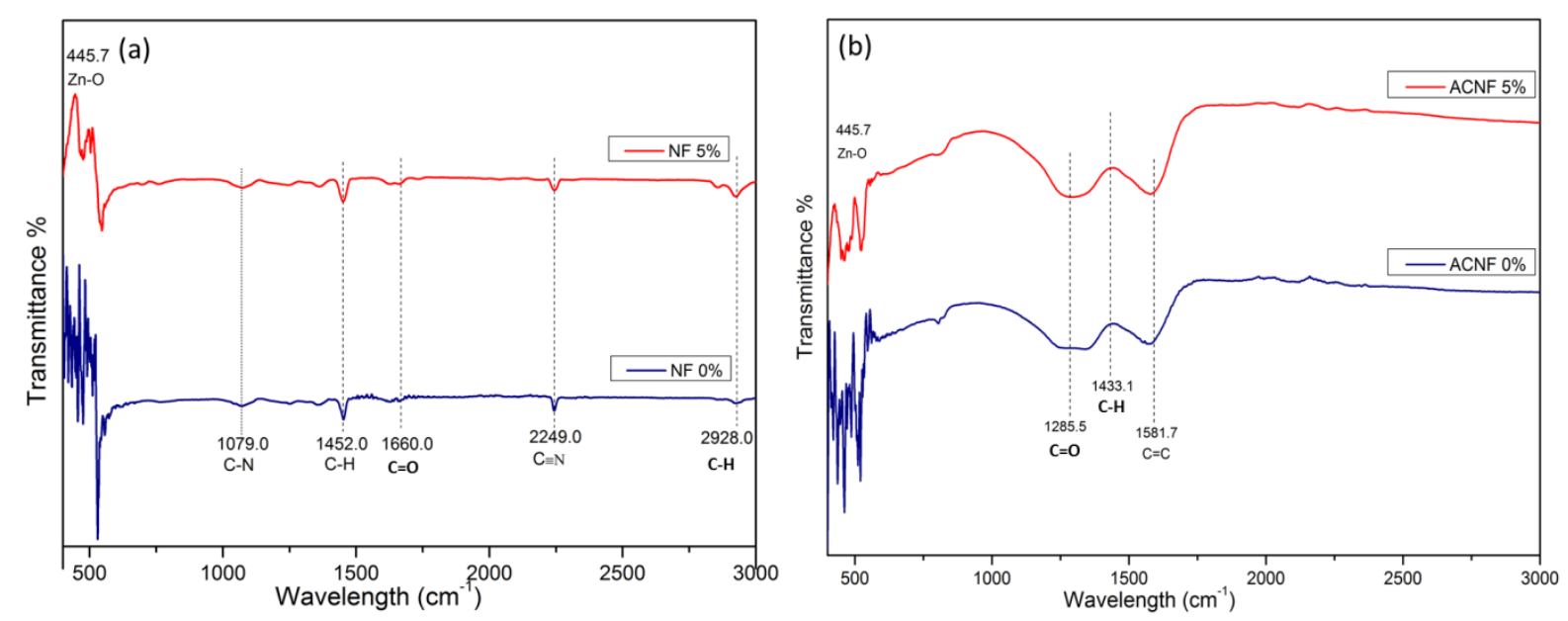

Figure 3. FTIR spectra of NF0 and NF5 (a) prior activation and (b) after activation

\section{Elemental analysis}

The crystallographical behaviors of both NF0 and NF5 prior and after activation have been analyzed by using X-ray diffraction analysis as shown in Figure 4. It can be seen that prior activation, the structure of the NFs is amorphous and after activation, the structure become more crystalline. As shown in Figure 4(a), the obvious peak detected at $16.7^{\circ}$ in NF0 represents the polymer PAN peak [12] while the other two sharp peaks that only appeared in NF5 at 31.85 and $36.3^{\circ}$ represents the $\mathrm{ZnO}$ peaks. However, in Figure 4(b), the polymer peak changed to carbon peak after activation and it was detected at $13.2^{\circ}$ [13]. As detected in Figure 4(a), the same $\mathrm{ZnO}$ peaks were also observed in ACNF5 with addition of two other $\mathrm{ZnO}$ peaks at 34.6 and $47.55^{\circ}$ [14 - 16]. It is believed these two peaks already appeared in the NF5; however it cannot be seen due to amorphous structure of the NFs.
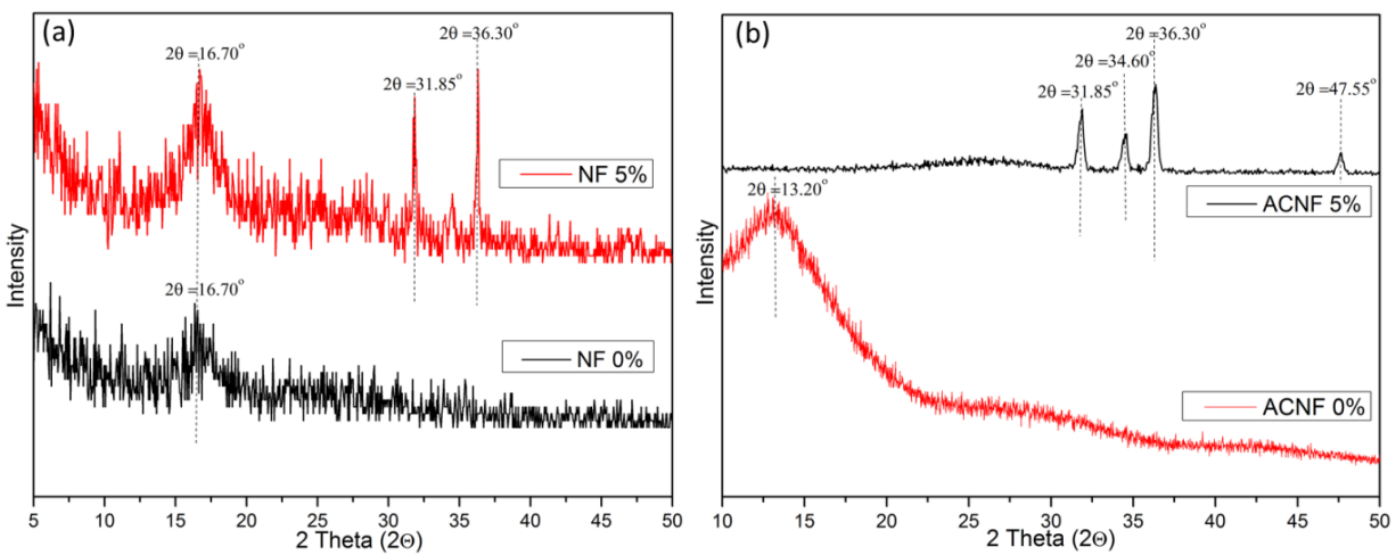

Figure 4. X-ray diffractogram of NF0 and NF5 (a) prior activation and (b) after activation

\section{BET surface area}

Brunauer-Emmett-Teller (BET) analysis was used to determine the specific surface area (SSA) of all resultant NFs as depicted in Table 1. Prior activation, the addition of low or high concentration of $\mathrm{ZnO}$ bring no effect to the enhancement of SSA of the NFs (see data in Table 1), in contrast it shows pristine NFs possessed the largest SSA. 
However, after heat treatment was conducted to the NFs, there is significant increment in SSA of NFs especially for ACNF5 that possessed total SSA of $163.04 \mathrm{~m}^{2} / \mathrm{g}$. The result obtained was comparable to the previous study conducted by Kahjwal and friends (2016) [16] as they obtained BET results of $137 \mathrm{~m}^{2} / \mathrm{g}$ after the calcination of NFs embedded with $\mathrm{ZnO}$ at $700{ }^{\circ} \mathrm{C}$.

However, the addition of 10 and $15 \%$ of $\mathrm{ZnO}$ into the NFs showed no significant increment in SSA even after activation as compared to the ACNFs with $5 \% \mathrm{ZnO}$. This phenomenon occurred due to the higher amount of $\mathrm{ZnO}$ (more than 5\%) could probably inhibited the catalytic effect of the $\mathrm{ZnO}$ that increasing the diameter of the resultant NFs and it also believed the fiber distribution became broader. As the diameter increases, the SSA are believed to reduce and it is important to note that the right amount of $\mathrm{ZnO}$ are the main concern in order to produce NFs with smaller diameter and high SSA. Higher specific surface area is believed could increase the adsorption performance due to increasing adsorption active sites [17].

Table 1. Comparison of specific surface area of nanofibers embedded with different concentration of $\mathrm{ZnO}$ prior and after activation

\begin{tabular}{lcc}
\hline Sample & $\begin{array}{c}\text { Prior activation } \\
\left(\mathbf{m}^{\mathbf{2}} \mathbf{g}\right)\end{array}$ & $\begin{array}{c}\text { After activation } \\
\left(\mathbf{m}^{2} / \mathbf{g}\right)\end{array}$ \\
\hline NF0 & 9.1300 & 3.9446 \\
NF5 & 8.9070 & 163.0416 \\
NF10 & 5.3658 & 29.1523 \\
NF15 & 7.4454 & 24.9459 \\
\hline
\end{tabular}

\section{Conclusion}

Thorough chemical, physical and thermal characterizations that have been employed in this study, the effects of incorporating $\mathrm{ZnO}$ in PAN-based $\mathrm{NFs}$ have been investigated. Composite $\mathrm{ACNF} / \mathrm{ZnO}$ after heat treatment possessed average diameter of $270 \mathrm{~nm}$ and SSA obtained ranging from 3.9446 to $163.0416 \mathrm{~m}^{2} / \mathrm{g}$. By using various type of characterization techniques like FE-SEM, BET, XRD, and FTIR, have provided better understanding on morphological and structural properties of PAN-based ACNFs embedded with various concentration of $\mathrm{ZnO}$.

\section{Acknowledgement}

The authors would like to acknowledge the financial support from the Malaysian Ministry Education and Universiti Teknologi Malaysia under GUP grant (Q.J130000.2542.05H46 and Q.J130000.2546.12H54) and Higher Institution Centre of Excellent (HiCoE) grant. One of the authors would also like to acknowledge the technical and management support from Research Management Centre (RMC), Universiti Teknologi Malaysia.

\section{References}

1. Diez, N., Díaz, P., Álvarez, P., González, Z., Granda, M., Blanco, C., Santamaría, R. and Menéndez, R. (2014). Activated carbon fibers prepared directly from stabilized fibers for use as electrodes in supercapacitors. Materials Letters, 136: $214-217$.

2. Liu, H. Q. and Hsieh, Y. L. (2002). Ultrafine fibrous cellulose membranes from electrospinning of cellulose acetate. Journal of Polymer Science B: Polymer Physics, 40: 2119 - 2129.

3. Alcañiz-Monge, J., Lozano-Castelló, D., Cazorla-Amorós, D. and Linares-Solano, A. (2009). Fundamentals of methane adsorption in microporous carbons. Microporous and Mesoporous Materials, 124(1-3): 110 - 116.

4. Díez, N., Alvarez, P., Granda, M., Blanco, C., Santamaria, R. and Menéndez, R. (2015). A novel approach for the production of chemically activated carbon fibers. Chemical Engineering Journal, 260: 463 - 468.

5. Kumar, P. R., Khan, N., Vivekanandhan, S., Satyanarayana, N., Mohanty, A. K., and Misra, M. (2012). Nanofibers: Effective generation by electrospinning and their applications. Journal of Nanoscience and Nanotechnology, 12: $1-25$. 
6. Dadvar, S., Tavanai, H. and Morshed, M. (2012). Effect of embedding $\mathrm{MgO}$ and $\mathrm{Al}_{2} \mathrm{O}_{3}$ nanoparticles in the precursor on the pore characteristics of PAN based activated carbon nanofibers. Journal of Analytical and Applied Pyrolysis, 98: 98 - 105.

7. Bhardwaj, N. and Kundu, S. C. (2010). Electrospinning: A fascinating fiber fabrication technique. Biotechnology Advances, 28: 325 - 347.

8. Venugopal, J., Zhang, Y. Z. and Ramakrishna, S. (2004). Electrospun nanofibres: biomedical applications. Proceedings of the Institution of Mechanical Engineers, Part N: Journal of Nanomaterials, Nanoengineering and Nanosystems, 218(1): 35 - 45.

9. Khalil, K. A., Sherif, E. M., Nabawy, A. M., Abdo, H. S., Marzouk, W. W. and Alharbi, H. F. (2016). Titanium carbide nanofibers-reinforced aluminium compacts, a new strategy to enhance mechanical properties. Materials, 9(5): 399 - 413.

10. Haroosh, H. J., Dong, Y., Chaudhary, D. S., Ingram, G. D. and Yusa, S. I. (2013). Electrospun PLA/PCL composites embedded with unmodified and 3-aminopropyltriethoxysilane (ASP) modified halleysite nanotubes (HNT). Applied Physics A: Materials Science and Processing, 110(2): 433 - 442.

11. Harish, K. and Renu, R. (2013). Structural and optical characterization of $\mathrm{ZnO}$ nanoparticles synthesized by microemulsion route. International Letters of Chemistry, Physical and Astronomy, 19: 26-36.

12. Sun, M., Lan, B., Lin, T., Cheng, G., Ye, F., Yu, L., Cheng, X. and Zheng, X. (2013). Controlled synthesis of nanostructured manganese oxide: crystalline evolution and catalytic activities. CrystEngComm, 15(35): 7010 7018.

13. Yusof, N. and Ismail, A. F. (2012). Post spinning and pyrolysis processes of polyacrylonitrile (PAN)-based carbon fiber and activated carbon fiber: A review. Journal of Analytical and Applied Pyrolysis, 93: 1 - 13.

14. Babu, K. S., Reddy, A. R., Sujatha, C., Reddy, K. V. and Mallika, A. N. (2013). Synthesis and optical characterization of porous ZnO. Journal of Advanced Ceramics, 2(3): 260 - 265.

15. Cipriani, E., Zanetti, M., Bracco, P., Brunella, V., Luda, M. P. and Costa, L. (2015) Crosslinking and carbonization processes in PAN films and nanofibers. Polymer Degradation and Stability, 123: 178 -188.

16. Kanjwal, M. A., Barakat, N. A., Sheikh, F. A., Park, D. K. and Kim, H. Y. (2010). Physicochemical characterizations of electrospun $\left(\mathrm{ZnO}-\mathrm{GeO}_{2}\right)$ nanofibers and their optical properties. Journal of Materials Science, 45(14): 3833 - 3840.

17. Im, J. S., Park, S. J., Kim, T. J., Kim, Y. H. and Lee, Y. S. (2009). The study of controlling pore size on electrospun carbon nanofibers for hydrogen adsorption. Journal of Colloid and Interface Science, 318 (1): 42 49. 